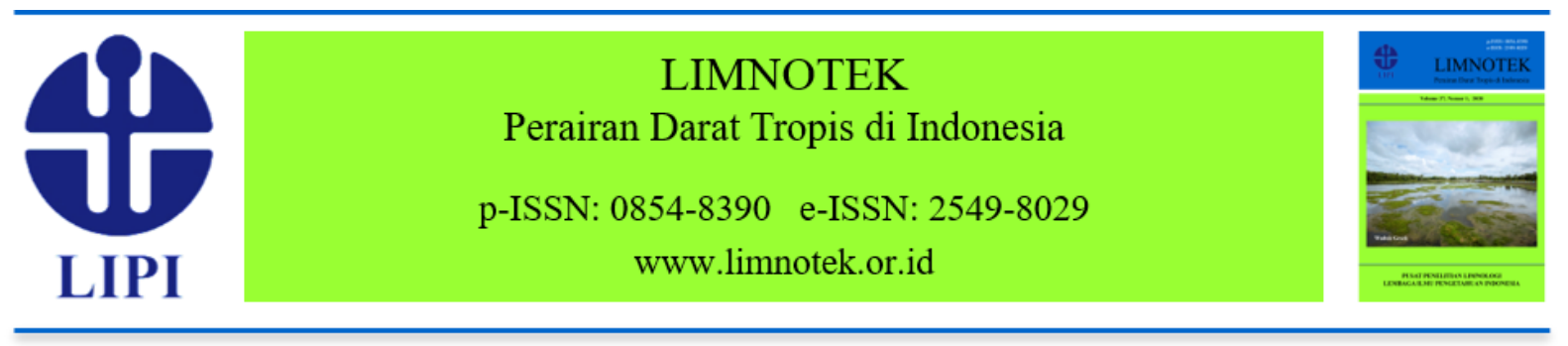

\title{
Keanekaragaman Makrofita dan Fitoplankton di Waduk Gesek, Pulau Bintan, Kepulauan Riau
}

\section{Winny Retna Melani, Tri Apriadi, Febrianti Lestari, Yoga Oktaliandi Saputra, Asmadi Hasan, Mas Ayu Ritia Mawaddah, Novi Fatmayanti}

Fakultas Ilmu Kelautan dan Perikanan, Universitas Maritim Raja Ali Haji, Tanjung Pinang

Email: tri.apriadi@umrah.ac.id

Diajukan 17 Oktober 2018. Ditelaah 8 Agustus 2019. Disetujui 12 Maret 2020.

\begin{abstract}
Abstrak
Waduk Gesek merupakan salah satu sarana penyedia air baku bagi masyarakat di Kota Tanjung Pinang, Pulau Bintan. Sejak tahun 2017, waduk ini sudah dipenuhi oleh berbagai tumbuhan air yang berpotensi mengganggu penyediaan cadangan air baku oleh PDAM. Penelitian ini bertujuan untuk mengetahui keanekaragaman makrofita dan fitoplankton serta kaitannya dengan kualitas perairan di Waduk Gesek. Pengambilan sampel dilakukan di tiga bagian waduk yang mewakili inlet, outlet, dan bagian tengah waduk. Sampel makrofita diambil menggunakan transek $1 \times 1 \mathrm{~m}^{2}$, sedangkan fitoplankton diambil menggunakan net plankton dengan metode statis. Dari penelitian ini, fitoplankton yang dijumpai berjumlah 31 genera, terdiri dari 12 genera Bacillariophyta, 16 genera Chlorophyta, dan 3 genera Cyanophyta. Karakteristik parameter fisika dan kimia perairan waduk yang khas dengan $\mathrm{pH}$ yang cukup asam menjadikan Chlorophyta sebagai fitoplankton dengan kelimpahan terbesar di Waduk Gesek, dengan spesies predominan Zygnema sp. Penelitian ini juga menemukan tiga spesies makrofita, yaitu gulma Brazil (Egeria densa), rumput air Kanada (Elodea canadensis), dan kangkung (Ipomoea aquatica). Gulma Brazil merupakan makrofita yang memiliki kerapatan tertinggi. Kerapatan gulma Brazil yang tinggi di semua titik pengamatan mengindikasikan bahwa spesies ini memiliki kemampuan adaptasi paling baik terhadap kondisi lingkungan perairan di Waduk Gesek. Hal ini perlu diwaspadai karena apabila tidak dikendalikan, maka tanaman air ini dapat mengganggu operasional penyediaan air baku oleh pihak PDAM Tirta Kepri. Kerapatan makrofita yang tinggi, selain akan mengurangi kelimpahan fitoplankton, dikhawatirkan akan memicu peningkatan dekomposisi di perairan Waduk Gesek, sehingga menyebabkan $\mathrm{pH}$ semakin asam.
\end{abstract}

Kata kunci: fitoplankton, keanekaragaman, makrofita, Pulau Bintan, Waduk Gesek 


\begin{abstract}
Biodiversity of Macrophytes and Phytoplankton in Gesek Reservoir, Bintan Island, Riau Islands. Gesek Reservoir is one of the facilities for providing water supply for the community in Tanjung Pinang City, Bintan Island. Since 2017, the reservoir has been filled with a variety of macrophytes that have the potential to disrupt the provision of raw water reserves by the Local Water Company (PDAM). The objective of this study was to determine the diversity of macrophytes and phytoplankton and their relationship with water quality in Gesek Reservoir. Sampling was carried out in three parts of the reservoir representing the inlet, outlet, and the center of the reservoir. Macrophyte samples were collected using $1 \mathrm{x} 1 \mathrm{~m}^{2}$ transect, while phytoplankton were sampled using plankton net by static methods. From this study, phytoplankton found were 31 genera, consisting of 12 Bacillariophyta genera, 16 Chlorophyta genera, and 3 Cyanophyta genera. Characteristics of physics and chemical parameters of typical reservoir waters with sufficiently acidic $\mathrm{pH}$ made Chlorophyta the largest abundance of phytoplankton in Gesek Reservoir, with predominant species Zygnema sp. The study also found three species of macrophytes, namely Brazilian waterweeds (Egeria densa), Canadian waterweeds (Elodea canadensis), and water spinach (Ipomoea aquatica). Brazilian waterweeds were macrophytes that have the highest density. The high density of Brazilian waterweeds indicated that this species has the best adaptability to the environmental conditions of the waters in Gesek Reservoir. This needs to be watched out because if it is not controlled, this water plant could disrupt the water supply operation by the PDAM Tirta Kepri. High macrophyte density, in addition to reducing phytoplankton abundance, is feared to trigger an increase in decomposition in the waters of Gesek Reservoir, causing a more acidic $\mathrm{pH}$.
\end{abstract}

Keywords: Bintan Island, diversity, macrophytes, phytoplankton, Gesek Reservoir

\section{Pendahuluan}

Pulau Bintan merupakan salah satu pulau kecil yang terletak di sebelah timur Pulau Sumatra dengan luas sekitar 1.167 $\mathrm{km}^{2}$ (DKP Kepri, 2018). Berdasarkan Surat Keputusan Menteri Kehutanan Nomor 328 Tahun 2009, salah satu Daerah Aliran Sungai (DAS) prioritas di Pulau Bintan adalah DAS Sei Jang yang meliputi wilayah administrasi Kota Tanjung Pinang dan Kabupaten Bintan. Pulau Bintan tidak memiliki sungai sebagaimana pulau besar, hanya ada anak sungai pendek yang langsung bermuara ke wilayah estuari. Hal ini yang menjadikan potensi sumber daya air di Pulau Bintan sangat terbatas, sehingga DAS Sei Jang yang ada ini menjadi DAS prioritas dalam menyediakan air tawar di Pulau Bintan, dengan Waduk Pulai dan Waduk Gesek.

Pembangunan di Pulau Bintan sejak pembentukan Provinsi Kepulauan Riau berlangsung sangat pesat mengingat telah ada tiga pusat pemerintahan, yaitu ibu kota provinsi, Kota Otonom Tanjung Pinang, dan ibu kota Kabupaten Bintan. Namun demikian, permasalahan lingkungan dan konflik kepentingan dalam pengelolaan sumber daya di pulau kecil ini masih selalu terjadi. Hal ini dikarenakan karakteristik pulau kecil yang sangat spesifik menimbulkan berbagai masalah lingkungan, salah satunya adalah jaminan ketersediaan air bersih dalam jumlah yang cukup dan kualitas yang baik.

Untuk memenuhi kebutuhan air baku di Pulau Bintan, maka Waduk Gesek mulai dibangun pada tahun 2011. Waduk ini diharapkan mampu membantu pemenuhan kebutuhan air baku di Pulau Bintan yang sebelumnya berasal dari Waduk Pulai, Kolong Enam, Waduk Lagoi, dan Waduk Jago (BWS Sumatera IV, 2019). Waduk Gesek memiliki luas genangan $\pm 6,82$ ha dengan volume tampungan $277.888 \mathrm{~m}^{3}$. 
Dalam beberapa tahun terakhir, kondisi kualitas perairan Waduk Gesek semakin menurun. Hal ini terlihat dari $\mathrm{pH}$ yang rendah (Apriadi et al., 2018) dan konsentrasi bahan organik (BOD) yang telah melebihi baku mutu perairan (Asmaniar, 2017). Kondisi ini berpotensi memicu pertumbuhan makrofita sebagai akibat peningkatan konsentrasi nutrien di perairan, sehingga menjadikan keberadaan tanaman air tersebut sebagai gulma (Pratiwi et al., 2010; Widjaja, 2004). Faktanya, sejak akhir tahun 2017 hampir seluruh badan perairan waduk dipenuhi oleh tumbuhan air (makrofita), seperti gulma Brazil (Egeria densa) dan rumput air Kanada (Elodea canadensis). Hal ini akan menjadi permasalahan, mengingat waduk ini dimanfaatkan sebagai cadangan air baku oleh PDAM Tirta Kepri.

Peningkatan konsentrasi nutrien yang ada di Waduk Gesek diduga disebabkan oleh masukan bahan organik dari limbah domestik permukiman warga di sekitar inlet waduk. Selain itu, keberadaan perkebunan kelapa sawit di daerah hulu aliran sungai yang menjadi sumber air bagi waduk ini diduga memberikan kontribusi terhadap penambahan nutrien di perairan. Berdasarkan pengamatan, Waduk Gesek juga memiliki permasalahan pengurangan volume air terutama pada musim kemarau. Penurunan volume air ini cenderung menyebabkan penetrasi cahaya matahari bisa mencapai dasar perairan. Hal ini juga yang dapat menjadi penyebab makrofita berlimpah di Waduk Gesek. Konsentrasi nutrien dan intensitas cahaya matahari yang tinggi merupakan pemicu utama peningkatan pertumbuhan biota autotrofik secara cepat di perairan menggenang (Ryding \& Rast, 1989).

Kajian yang telah dilakukan di Waduk Gesek yaitu keanekaragaman ikan (Apriadi et al., 2018) dan kualitas air (Asmaniar, 2017), namun kajian tentang keberadaan organisme autotrofik seperti makrofita dan fitoplankton belum pernah dilaporkan. Penelitian ini bertujuan untuk mengetahui keanekaragaman makrofita dan fitoplankton serta hubungannya dengan kualitas perairan Waduk Gesek. Hasil penelitian ini diharapkan dapat bermanfaat sebagai informasi dasar untuk pengelolaan Waduk Gesek yang berkelanjutan.

\section{Bahan dan Metode}

Untuk memperoleh data biota autotrofik dan karakteristik kualitas air yang representatif, pengambilan sampel dilakukan di 15 titik yang tersebar di Waduk Gesek, yang mewakili bagian hulu (dua inlet dari aliran Sungai Gesek, masing-masing tiga titik), masukan ke saluran PDAM dan bagian tengah waduk (enam titik), serta bagian hilir atau outlet (tiga titik). Pengambilan sampel dilakukan pada bulan Juni 2018. Lokasi pengambilan sampel diperlihatkan dalam Gambar 1.

Sampel air sebanyak 3 L diambil menggunakan Vandorn water sampler untuk mengetahui kualitas air. Sebanyak tiga kali ulangan dilakukan dalam mengambil sampel air di setiap titik sampling. Parameter kualitas air yang diamati terdiri dari parameter fisika perairan (suhu, kejernihan, TSS, dan kekeruhan), parameter kimia ( $\mathrm{pH}$, DO, dan BOD), serta parameter biologi (kerapatan makrofita dan kelimpahan fitoplankton). Suhu, $\mathrm{pH}$, dan DO diukur menggunakan Multitester Lutron YK 2005 WA. Kejernihan air diukur menggunakan Secchi disk, sedangkan kekeruhan dengan TN-100 waterproof Turbidimeter. BOD diukur menggunakan metode inkubasi dan titrasi Winkler, sedangkan TSS dianalisis menggunakan metode gravimetri (APHA, 2012). Analisis parameter fisika dan kimia perairan dilakukan di Laboratorium Kimia Kelautan FIKP UMRAH. 


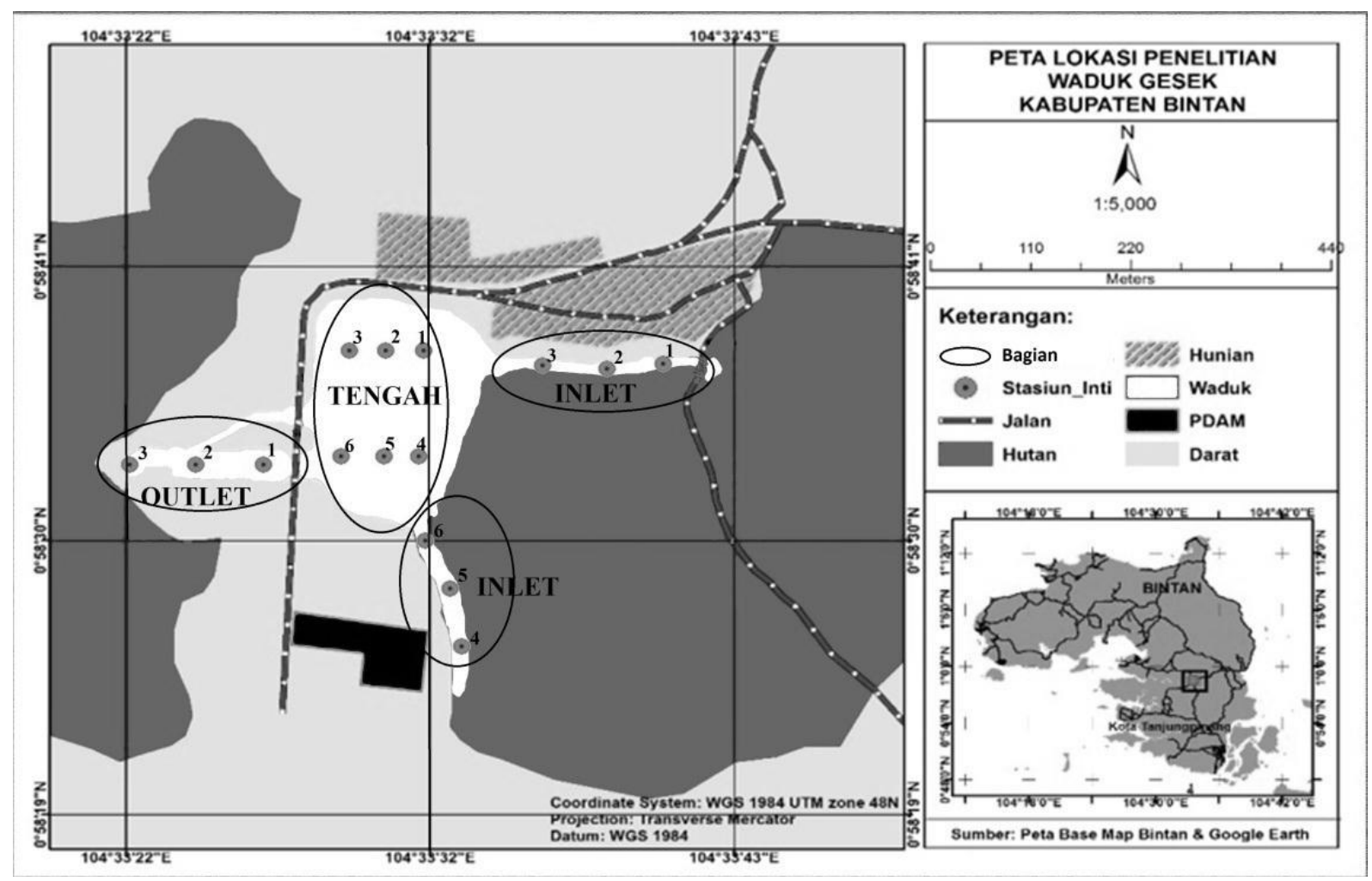

Gambar 1. Lokasi pengambilan sampel di Waduk Gesek

Sampel makrofita diambil menggunakan transek $1 \times 1 \mathrm{~m}^{2}$ di setiap titik pengamatan. Terdapat tiga transek sebagai ulangan di setiap titik sampling. Sampel fitoplankton diambil dengan menyaring 100 liter air menggunakan net plankton no. 25 berukuran mata jaring $40 \mu \mathrm{m}$ dengan metode statis. Identifikasi makrofita dan fitoplankton dilakukan di Laboratorium Biologi Kelautan, FIKP UMRAH.

Makrofita diidentifikasi menggunakan buku identifikasi Pancho dan Soerjani (1978), Sastrapradja dan Bimantoro (1981), Fassett (1960), Cook et al. (1974), serta Prescott (1969). Kerapatan makrofita dihitung dengan membandingkan jumlah tegakan individu dengan luas transek $\left(1 \mathrm{~m}^{2}\right)$. Fitoplankton yang dijumpai diidentifikasi menggunakan buku identifikasi Davis (1955) dan Prescott (1970). Kelimpahan fitoplankton dihitung menggunakan Sedgewick Rafter Counting Cell (SRC) dengan metode sensus berdasarkan rumus APHA (2012). Kesamaan jenis makrofita dan fitoplankton antara stasiun dianalisis melalui pendekatan indeks similaritas Bray Curtis (Krebs, 2014; Odum, 1993).

\section{Hasil}

Makrofita di perairan Waduk Gesek dijumpai sebanyak tiga spesies, yaitu gulma Brazil (Egeria densa), rumput air Kanada (Elodea canadensis), dan kangkung (Ipomoea aquatica) (Tabel 1). Gulma Brazil merupakan spesies dengan kerapatan tertinggi di seluruh bagian waduk.

Fitoplankton yang dijumpai di perairan Waduk Gesek berjumlah 31 genera (Tabel 2), terdiri dari divisi Bacillariophyta 12 genera, Chlorophyta 16 genera, dan Cyanophyta tiga genera. Kelimpahan fitoplankton terbanyak dijumpai di bagian outlet. Chlorophyta merupakan kelompok fitoplankton yang paling berlimpah (Gambar 2) dengan proporsi kelimpahan mencapai $57 \%$ di bagian inlet, $94 \%$ di bagian tengah, dan $89 \%$ di bagian outlet waduk. 
Tabel 1. Makrofita di perairan Waduk Gesek

\begin{tabular}{ccccc}
\hline \multirow{2}{*}{ No. } & \multirow{2}{*}{ Makrofita } & \multicolumn{3}{c}{ Kerapatan (ind $/ \mathrm{m}^{2}$ ) } \\
\cline { 3 - 5 } & & Inlet & Tengah & Outlet \\
\hline 1 & Egeria densa & 59,1 & 19,7 & 48,6 \\
2 & Elodea canadensis & 36,7 & 6,0 & - \\
3 & Ipomoea aquatica & - & 0,1 & - \\
\hline \multicolumn{2}{c}{ Total } & 95,8 & 25,8 & 48,6 \\
\hline
\end{tabular}

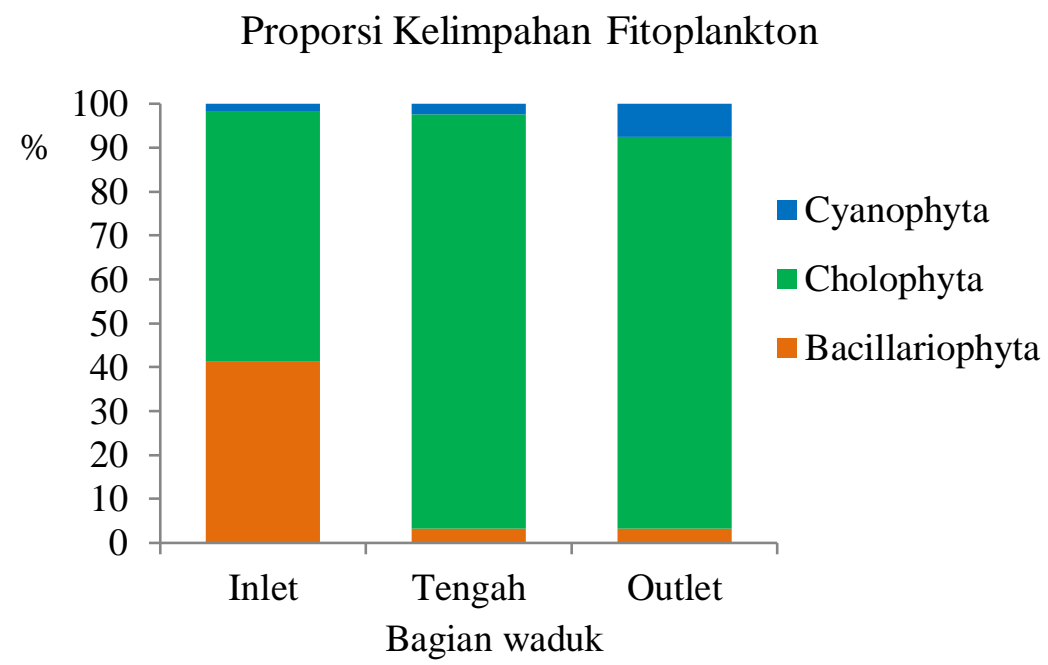

Gambar 2. Proporsi kelimpahan fitoplankton berdasarkan divisi di perairan Waduk Gesek

Berdasarkan indeks similaritas makrofita dan fitoplankton, diketahui bahwa di perairan Waduk Gesek terdapat dua klaster (Gambar 3 dan 4). Klaster 1 adalah bagian inlet, sedangkan klaster 2 terdiri dari bagian tengah dan outlet. Hal ini menandakan bahwa bagian tengah dan outlet waduk memiliki karakteristik yang hampir sama, baik ditinjau dari kerapatan makrofita (taraf kesamaan 97,27\%), maupun kelimpahan fitoplankton (taraf kesamaan $77,15 \%$ ).
Beberapa parameter fisika dan kimia perairan di Waduk Gesek masih memenuhi baku mutu untuk air baku kelas I berdasarkan PP No. 82 Tahun 2001, kecuali nilai TSS di outlet dan nilai $\mathrm{pH}$ di semua stasiun (Tabel 3). Konsentrasi TSS yang paling tinggi di outlet diduga karena ada akumulasi sedimen dari inlet dan bagian tengah waduk yang terbawa massa air, terutama saat pintu air dibuka. 
Tabel 2. Spesies dan kepadatan fitoplankton di perairan Waduk Gesek

\begin{tabular}{|c|c|c|c|c|}
\hline \multirow{2}{*}{ Divisi } & \multirow{2}{*}{ Spesies } & \multicolumn{3}{|c|}{ Kepadatan fitoplankton (sel/L) } \\
\hline & & Inlet & Tengah & Outlet \\
\hline \multirow[t]{12}{*}{ Bacillariophyta } & Mougeotiopsis sp. & 29 & 2 & 0 \\
\hline & Diatoma sp. & 37 & 0 & 36 \\
\hline & Pleurosigma sp. & 1 & 0 & 0 \\
\hline & Rhizosolenia sp. & 6 & 2 & 8 \\
\hline & Ephitemia sp. & 1 & 0 & 1 \\
\hline & Climacosphenia sp. & 1 & 0 & 0 \\
\hline & Nitzschia sp. & 1 & 2 & 0 \\
\hline & Acanthes sp. & 0 & 1 & 1 \\
\hline & Fragilaria sp. & 0 & 31 & 0 \\
\hline & Lyngbya sp. & 0 & 1 & 0 \\
\hline & Surirella sp. & 0 & 0 & 1 \\
\hline & Asterionella sp. & 0 & 0 & 6 \\
\hline \multirow[t]{16}{*}{ Chlorophyta } & Stigeocium sp. & 77 & 34 & 0 \\
\hline & Micrasterias sp. & 7 & 149 & 10 \\
\hline & Closterium sp. & 3 & 2 & 0 \\
\hline & Schroderia sp. & 1 & 0 & 0 \\
\hline & Zygnema sp. & 15 & 708 & 1.367 \\
\hline & Netrium sp. & 0 & 82 & 0 \\
\hline & Spirogyra sp. & 0 & 69 & 11 \\
\hline & Cosmarium sp. & 0 & 15 & 0 \\
\hline & Triploceras sp. & 0 & 1 & 0 \\
\hline & Scenedesmus sp. & 0 & 7 & 0 \\
\hline & Mougeotia sp. & 0 & 14 & 47 \\
\hline & Euastrum sp. & 0 & 1 & 1 \\
\hline & Crucigenia sp. & 0 & 1 & 0 \\
\hline & Hyalotheca sp. & 0 & 20 & 0 \\
\hline & Staurastrum sp. & 0 & 2 & 0 \\
\hline & Pleurotaenium sp. & 0 & 2 & 0 \\
\hline \multirow[t]{4}{*}{ Cyanophyta } & Phormidium sp. & 3 & 0 & 0 \\
\hline & Spirulina sp. & 0 & 18 & 0 \\
\hline & Oscillatoria sp. & 0 & 11 & 122 \\
\hline & Total & 178 & 1.170 & 1.611 \\
\hline
\end{tabular}




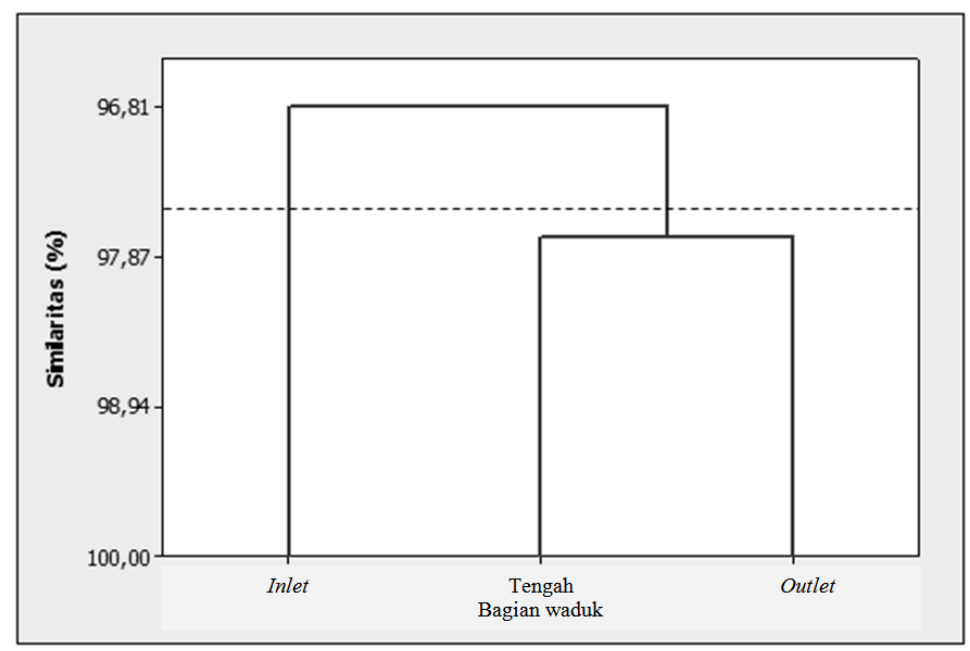

Gambar 3. Dendrogram kerapatan makrofita di perairan Waduk Gesek

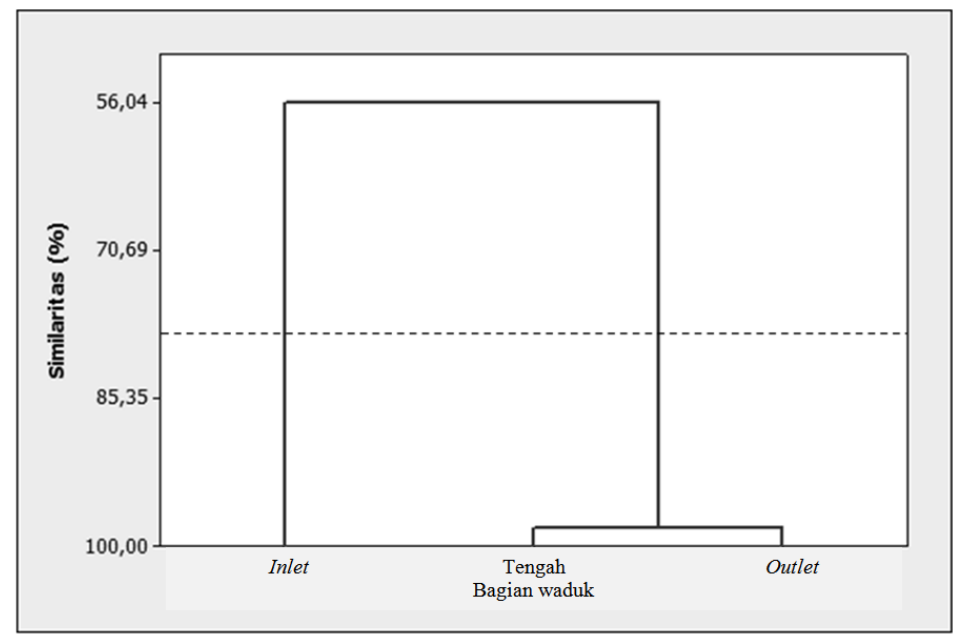

Gambar 4. Dendrogram kepadatan fitoplankton di perairan Waduk Gesek

Tabel 3. Nilai rata-rata parameter fisika dan kimia perairan Waduk Gesek

\begin{tabular}{|c|c|c|c|c|c|}
\hline \multirow{2}{*}{ No. } & \multirow{2}{*}{ Parameter } & \multicolumn{3}{|c|}{ Nilai rata-rata } & \multirow{2}{*}{ Baku mutu* } \\
\hline & & Inlet & Tengah & Outlet & \\
\hline \multicolumn{6}{|c|}{ Parameter Fisika } \\
\hline 1 & Suhu $\left({ }^{\circ} \mathrm{C}\right)$ & $28,3 \pm 0,7$ & $31,7 \pm 0,9$ & $28,5 \pm 1,0$ & deviasi 3 \\
\hline 2 & Kejernihan $(\mathrm{cm})$ & $84,4 \pm 18,4$ & $71,7 \pm 31,1$ & $45,8 \pm 4,0$ & \\
\hline 3 & $\mathrm{TSS}(\mathrm{mg} / \mathrm{L})$ & $40,0 \pm 8,5$ & $46,0 \pm 9,9$ & $52,0 \pm 0,0$ & 50 \\
\hline 4 & Kekeruhan (NTU) & $10,0 \pm 1,3$ & $7,6 \pm 0,5$ & $10,4 \pm 2,6$ & \\
\hline \multicolumn{6}{|c|}{ Parameter Kimia } \\
\hline 1 & $\mathrm{pH}$ & $5,70 \pm 0,07$ & $5,70 \pm 0,14$ & $5,23 \pm 0,20$ & $6-9$ \\
\hline 2 & $\mathrm{DO}(\mathrm{mg} / \mathrm{L})$ & $7,80 \pm 0,74$ & $7,47 \pm 0,50$ & $8,50 \pm 0,17$ & 4 \\
\hline 3 & BOD (mg/L) & $1,68 \pm 0,46$ & $1,80 \pm 0,30$ & $1,77 \pm 0,21$ & 3 \\
\hline
\end{tabular}

*Baku Mutu air kelas I berdasarkan Peraturan Pemerintah Republik Indonesia No. 82 Tahun 2001 


\section{Pembahasan}

\section{Makrofita}

Waduk Gesek mengalami permasalahan blooming makrofita gulma Brazil pada bulan April 2018 (Aminnudin, 2018). Keberadaan spesies ini telah menjadi permasalahan yaitu mengganggu operasional penyediaan air baku di Waduk Gesek. Berdasarkan hasil penelitian, kerapatan gulma Brazil yang tinggi di semua bagian waduk mengindikasikan bahwa spesies ini memiliki kemampuan adaptasi paling baik terhadap kondisi lingkungan perairan Waduk Gesek. Casati et al. (2000) melaporkan bahwa gulma Brazil memiliki phosphoenolpyruvate carboxylase (PEPC) dan NADP-malic enzyme (NADP-ME) yang mampu memberikan ekspresi dan respons metabolisme fotosintesis, baik pada temperatur tinggi maupun temperatur rendah. Hal ini sangat memengaruhi kemampuan fotosintesis gulma Brazil pada berbagai kondisi. Lebih lanjut dinyatakan oleh Yarrow et al. (2009), gulma Brazil merupakan tumbuhan air dengan pertumbuhan yang cepat dan umumnya akan mendominasi suatu ekosistem perairan terutama perairan dangkal dan jernih, sehingga menjadi spesies invasif (Mony et al., 2007).

Rumput air Kanada tidak dijumpai di outlet Waduk Gesek. Hal ini diduga akibat pengaruh keberadaan pintu air (dam) dengan aliran air yang cukup deras saat keluar dari waduk. Selain itu, keberadaan gulma Brazil dengan kerapatan yang tinggi di bagian outlet diduga menjadi kompetitor dalam relung ekologi rumput air Kanada. Di bagian inlet, kerapatan gulma Brazil lebih tinggi, namun kerapatan rumput air Kanada juga tertinggi. Hal ini diduga karena pengaruh input nutrien di bagian inlet waduk.

Erhard dan Gross (2006) menyatakan bahwa rumput air Kanada memiliki korelasi negatif dengan keberadaan fitoplankton. Hal ini berkaitan dengan kemampuan rumput air Kanada dalam aktivitas alelopati, yaitu dapat menghambat pertumbuhan Cyanobacteria dan fitoplankton. Rumput air Kanada merupakan spesies invasif dalam suatu ekosistem perairan (Bowmer et al., 1995), sehingga apabila tidak dikendalikan maka tanaman air ini dapat menjadi gulma.

Kangkung hanya dijumpai di bagian tengah waduk. Hal ini diduga terkait dengan kecepatan aliran air yang lebih rendah dibandingkan inlet yang memiliki aliran masuk dari sungai kecil dan outlet yang memiliki aliran keluar. Kecepatan aliran memiliki pengaruh yang signifikan terhadap laju pertumbuhan kangkung karena kecepatan arus yang tinggi akan mengurangi kemampuan kangkung dalam menyerap nitrat dan fosfat (Endut et al. 2009). Prasad et al. (2008) menyatakan bahwa kangkung merupakan salah satu tumbuhan tipe mengapung bebas yang umumnya dijumpai di berbagai ekosistem perairan tawar, terutama ekosistem perairan menggenang (lentik).

\section{Fitoplankton}

Kelimpahan fitoplankton yang rendah di stasiun inlet selain diduga akibat aliran air masuk ke waduk, juga dipengaruhi oleh kerapatan yang tinggi dari makrofita gulma Brazil. Hal ini sesuai dengan Mazzeo et al. (2003) yang menyatakan bahwa gulma Brazil memiliki efek yang negatif terhadap kelimpahan fitoplankton, terutama dalam hal pemanfaatan nutrien dan pembatasan cahaya. Selain itu, Nofdianto dan Tanjung (2019) menyatakan bahwa kerapatan makrofita memiliki korelasi negatif terhadap keanekaragaman dan kepadatan mikroalga epifiton. Hal ini berkaitan dengan penghalangan intensitas cahaya oleh tutupan makrofita.

Kelimpahan Chlorophyta di perairan Waduk Gesek didukung oleh keberadaan Zygnema sp. yang banyak dijumpai di bagian tengah waduk dan outlet. Zygnema sp. seringkali juga disebut Zygogonium sp. (Stancheva et al., 2012), memiliki persebaran yang sangat luas, mulai dari kutub hingga perairan terestrial di tropika (Pichrtová et al., 2016; Pichrtová et al., 2014 ${ }^{\text {b }}$ Holzinger, 2009). Pembentukan praakinet pada Zygnema sp. dan umumnya pada 
Chlorophyta berfilamen, berperan sangat penting dalam menetralisasi tekanan lingkungan, terutama saat nitrogen terbatas dan air yang minim (Pichrtová et al., 2014 ${ }^{\text {, }}$ Pichrtová et al., 2014ª). Pra-akinet ini juga berperan dalam proses pertumbuhan setelah Chlorophyta melewati masa istirahat (dorman). Hal ini yang menyebabkan kelimpahan Zygnema sp. yang banyak di perairan Waduk Gesek. Kelimpahan Zygnema sp. yang sangat sedikit di bagian inlet diduga disebabkan kerapatan makrofita gulma Brazil dan rumput air Kanada yang tinggi.

\section{Indeks Similaritas}

Bagian inlet yang membentuk satu klaster tersendiri dapat disebabkan bagian waduk tersebut memiliki kerapatan makrofita tertinggi, tetapi dengan kelimpahan fitoplankton terendah. Kondisi ini menunjukkan perbedaan yang sangat besar dari kondisi di bagian tengah dan outlet waduk. Tumbuhan air yang padat di bagian inlet diduga dapat menghalangi penetrasi cahaya matahari ke dalam kolom perairan, sehingga mengganggu fotosintesis fitoplankton. Seperti diketahui bahwa intensitas cahaya matahari merupakan faktor penting dalam produktivitas primer fitoplankton (Gao et al., 2012).

\section{Parameter Fisika dan Kimia Perairan}

Nilai $\mathrm{pH}$ di semua titik pengamatan di bawah 6, ini mengindikasikan perairan Waduk Gesek tergolong asam. Menurut Apriadi et al. (2018), nilai $\mathrm{pH}$ di perairan alami Pulau Bintan berkisar 4,48-6,88, sedangkan nilai $\mathrm{pH}$ di perairan bekas tambang bauksit di Pulau Bintan berkisar 4,45-6,36 (Putra et al., 2018), 4,00 (Apriadi \& Ashari, 2018), serta 5,46-6,13 (Apriadi et al., 2018). Nilai $\mathrm{pH}$ yang rendah diduga dipengaruhi oleh kondisi sedimen di Pulau Bintan yang mengandung bauksit (Sembiring, 2008). Nilai $\mathrm{pH}$ yang rendah di perairan Waduk Gesek diduga juga dipengaruhi oleh proses dekomposisi bahan organik yang terjadi sejak awal penggenangan waduk. Selain itu, makrofita gulma Brazil yang tumbuh dengan kerapatan tinggi juga dapat menjadi penyumbang bahan organik autochthonous.

Kondisi ekosistem waduk mulai stabil setelah sepuluh tahun penggenangan (Kartamiharja, 2008). Pada periode awal penggenangan, umumnya kondisi waduk masih belum stabil, seperti halnya Waduk Gesek yang baru digenangi tujuh tahun. Kartamiharja (2008) juga menjelaskan bahwa terdapat tren penurunan rentang nilai pH di Waduk Ir. Djuanda (Jatiluhur) sebelum dan setelah penggenangan.

Secara umum, parameter fisika dan kimia perairan di Waduk Gesek sudah memenuhi baku mutu. Kekeruhan dan konsentrasi TSS yang tinggi di bagian outlet waduk diduga akibat akumulasi bahan organik, terutama saat pintu air dibuka. Akumulasi bahan organik di sedimen waduk akan semakin bertambah seiring dengan peningkatan aktivitas antropogenik, misalnya budi daya perikanan (Warsa \& Astuti, 2020; Lukman \& Hidayat, 2002) dan berpengaruh terhadap produktivitas perairan (Yuningsih et al., 2014).

Fatmayanti et al. (2019) melaporkan bahwa perairan Waduk Pulai yang memiliki konsentrasi bahan organik lebih besar daripada Waduk Gesek memiliki kelimpahan fitoplankton yang didominasi oleh Bacillariophyta dan diikuti oleh Chlorophyta dengan kelimpahan tertinggi yaitu Navicula sp. Selain itu, Apriadi dan Ashari (2018) menyebutkan bahwa perairan kolong bauksit di Pulau Bintan yang memiliki $\mathrm{pH}$ lebih rendah daripada Waduk Gesek didominasi oleh fitoplankton Mougeotia sp. Hal ini dapat mengindikasikan bahwa parameter fisika dan kimia perairan memberikan pengaruh terhadap keanekaragaman jenis biota di waduk.

\section{Kesimpulan}

Keanekaragaman jenis makrofita dan fitoplankton di Waduk Gesek dipengaruhi oleh karakteristik parameter fisika dan kimia 
perairannya, dalam hal ini pHnya yang cukup asam menjadikan Chlorophyta sebagai fitoplankton predominan di waduk ini. Kepadatan gulma Brazil yang tinggi di semua titik pengamatan mengindikasikan bahwa jenis ini memiliki kemampuan adaptasi paling baik terhadap kondisi lingkungan perairan di Waduk Gesek. Hal ini perlu diwaspadai karena apabila tidak dikendalikan maka tanaman air ini dapat mengganggu operasional penyediaan air baku oleh pihak PDAM Tirta Kepri. Selain itu, kerapatan makrofita yang tinggi dikhawatirkan menjadi pemicu peningkatan dekomposisi di perairan Waduk Gesek, sehingga menyebabkan $\mathrm{pH}$ semakin asam. Keberadaan gulma Brazil yang dijumpai di seluruh bagian Waduk Gesek perlu ditindaklanjuti dengan kajian berikutnya seperti pengaruh kecepatan aliran, konsentrasi nutrien (nitrat dan fosfat), intensitas cahaya, dan bahan organik substrat.

\section{Ucapan Terima Kasih}

Ucapan terima kasih disampaikan kepada pihak Lembaga Penelitian dan Pengabdian kepada Masyarakat, Universitas Maritim Raja Ali Haji (LP3M UMRAH) atas kesempatan yang diberikan kepada penulis untuk melaksanakan riset melalui dana hibah internal UMRAH (Skim Penelitian Unggulan Perguruan Tinggi). Penulis juga mengucapkan terima kasih kepada Bapak Dimas Angga Hedianto (Balai Riset Pemulihan Sumber Daya Ikan, Kementerian Kelautan dan Perikanan) atas bantuan referensi serta informasi mengenai waduk.

\section{Referensi}

Aminnudin. 2018. Terancam Lumut Ini, PDAM Tirta Kepri Segera Sterilkan Waduk Gesek! Ini Alasannya! Tribunbintan.com. 3 April 2018. http://sda.pu.go.id/bwssumatera4/teranca m-lumut-ini-pdam-tirta-kepri segerasterilkan-waduk-gesek-ini-alasannya/. diakses tanggal 8 Oktober 2018

American Public Health Association (APHA). 2012. Standard Methods for the Examination of Water and Wastewater. $22^{\text {nd }}$ ed. American Public Health Association, Virginia, USA

Apriadi T, Ashari I. 2018. Struktur Komunitas Fitoplankton pada Kolong Pengendapan Limbah Tailing Bauksit di Senggarang, Tanjung Pinang. Majalah Ilmiah Biologi Biosfera - A Scientific Journal 35(3): 145-152

Apriadi T, Pratama G, Putra RD, Jumsurizal, Jaya YV, Firdaus M, Apras HD, Suryanti A. 2018. Comparative Study on the Fish Diversity from Natural and Bauxite Postmining in Wetland System of Bintan Island, Indonesia. Biodiversitas 19(3): 963-969

Asmaniar. 2017. Kualitas Sumber Air Baku Waduk Gesek Kabupaten Bintan Provinsi Kepulauan Riau. Skripsi. Jurusan Manajemen Sumberdaya Perairan, Fakultas Ilmu Kelautan dan Perikanan, Universitas Maritim Raja Ali Haji. Tanjung Pinang

Bowmer KH, Jacobs SWL, Sainty GR. 1995. Identification, Biology and Management of Elodea canadensis, Hydrocharitaceae. Journal Aquatic Plant Management 33: 13-19

Badan Wilayah Sungai Sumatra IV (BWS Sumatra IV). 2019. Pembangunan Tampungan Air Baku Sei Gesek. Diakses dari sda.pu.go.id/bwssumatera4/wpcontent/uploads/2019/09/Leaflet-SeiGesek.pdf. Diakses tanggal 19 Maret 2020

Casati P, Lara MV, Andreo SC. 2000. Induction of a C4-Like Mechanism of $\mathrm{CO}_{2}$ Fixation in Egeria densa, a Submersed Aquatic Species. Plant Physiologist 123: 1611-1621

Cook CDK, Gut BJ, Rix EM, Schneller JS, Seitz M. 1974. Water Plants of The World: A Manual fot The Identification of The Genera of Freshwater Macrophytes. Dr. W. Junk bv Publisher. England 
Davis CC. 1955. The Marine and Fresh Water Plankton. Michigan State University Press. Michigan, USA

Dinas Kelautan dan Perikanan Provinsi Kepulauan Riau (DKP Kepri). 2018. Penyediaan Data Series Keanekaragaman Hayati dan Sumber Daya Ikan di Kawasan Konservasi Perairan. KKP Kabupaen Bintan. Laporan Akhir. Tanjung Pinang: Dinas Kelautan dan Perikanan Provinsi Kepulauan Riau bekerja sama dengan Pusat Pelatihan dan Pengembangan Karir (P3K) Universitas Maritim Raja Ali Haji

Endut A, Jusoh A, Ali N, Nik WNSW, Hassan A. 2009. Effect of Flow Rate on Water Quality Parameters and Plant Growth of Water Spinach (Ipomoea aquatica) in an Aquaponic Recirculating System. Desalination and Water Treatment 5: 19-28

Erhard D, Gross EM. 2006. Gross Allelopathic activity of Elodea canadensis and Elodea nuttallii against epiphytes and phytoplankton. Aquatic Botany 85: 203-211

Fassett NC. 1960. A Manual of Aquatic Plants. The University of Wisconsin Press. Madison USA

Fatmayanti N, Apriadi T, Melani WR. 2019. Fitoplankton sebagai Bioindikator Kualitas Perairan pada Zona Litoral Waduk Sei Pulai, Pulau Bintan, Kepulauan Riau. DEPIK 8(3): 176-186

Gao K, Xu J, Gao G, Li Y, Hutchins DA, Huang B, Wang L, Zheng Y, Jin P, Cai X, Hader DP, Li W, Xu K, Liu N, Riebesell U. 2012. Rising $\mathrm{CO}_{2}$ and Increased Light Exposure Synergistically Reduce Marine Primary Productivity. Nature Climate Change 2: 519-523

Holzinger A, Roleda MY, Lütz C. 2009. The Vegetative Arctic Freshwater Green Alga Zygnema is Insensitive to Experimental UV Exposure. Micron 40(8): 831-838

Kartamiharja ES. 2008. Perubahan Komposisi Komunitas Ikan dan Faktorfaktor Penting yang Memengaruhi Selama Empat Puluh Tahun Umur
Waduk Djuanda. Jurnal Ikhtiologi Indonesia 8(2): 67-78

Krebs CJ. 2014. Ecological Methodology, $3^{\text {rd }} \quad e d$ Online access. http://www.zoology.ubc.ca/ krebs/books .html

Lukman, Hidayat. 2002. Pembebanan dan Distribusi Bahan Organik di Waduk Cirata. Jurnal Teknologi Lingkungan 3(2): 129-135

Mazzeo N, Rodriguez-Gallego L, Kruk C, Meerhoff M, Gorga J, Lacerot G, Quintans F, Loureiro M, Larrea D, Garcia-Rodriguez F. 2003. Effect of Egeria densa Planch. Beds on a Shallow Lake Without Piscivorous Fish. Hydrobiologia 506 (1-3): 591-602

Mony C, Koschnick TJ, Haller WT, Miller S. 2007. Competition Between Two Invasive Hydrocharitaceae (Hydrilla verticillata (L.f.) (royle) and Egeria densa (Planch)) as Influenced by Sediment Fertility and Season. Aquatic botany 86: 236-242

Nofdianto, Tanjung LR. 2019. Kerapatan Populasi Makrofita Berpengaruh terhadap Kelimpahan dan Keanekaragaman Makroalga Epifiton di Danau Tempe. LIMNOTEK Perairan Darat Tropis di Indonesia 6(2): 131-151

Odum EP. 1993. Dasar-dasar Ekologi Edisi Ketiga. Penerjemah Samingan T, Editor Srigando. Gadjah Mada University Press. Yogyakarta

Pancho JV, Soerjani M. 1978. Aquatic Weeds of Southeast Asia. National Publishing Cooperative Incorporated. Los Banos Filipina

Peraturan Pemerintah Republik Indonesia No. 82 Tahun 2001 tentang Pengelolaan Kualitas Air dan Pengendalian Pencemaran Air

Pichrtová M, Hájek T, Elster J. 2016. Annual Development of Mat-Forming Conjugating Green Algae Zygnema spp. In Hydro-terrestrial Habitats in the Arctic. Polar Biology 39(9): 1653-1662

Pichrtová M, Hájek T, Elster J. 2014 a . Osmotic Stress and Recovery in Field Populations of Zygnema sp. 
(Zygnematophyceae, Streptophyta) on Svalbard (High Arctic) Subjected to Natural Desiccation. EMS Microbiology Ecology 89(2): 270-280

Pichrtová M, Kulichová J, Holzinger A. $2014^{\mathrm{b}}$. Nitrogen Limitation and Slow Drying Induce Desiccation Tolerance in Conjugating Green Algae (Zygnematophyceae, Streptophyta) from Polar Habitats. PLoS ONE 9(11): e113137.https://doi.org/10.1371/journal. pone. 0113137

Prasad KN, Shivamurthy GR, Aradhya SM. 2008. Ipomoea aquatica, an Underutilized Green Leafly Vegetable: A Riview. International Journal of Botany 4(1): 123-129

Pratiwi NTM, Krisanti M, Maryanto I. 2010. Indikator Kerusakan Ekosistem Perairan Darat. Editor Musluhidin, Nooryanto B, Harmono S. Kementerian Lingkungan Hidup, Jakarta

Prescott GW. 1969. The Aquatic Plants. WM C Brown Company Publisher. Iowa

Prescott GW. 1970. The Freshwater Algae. WM C Brown Company Publisher. Iowa

Putra RD, Apriadi T, Suryanti A, Irawan H, Raja'i TS, Yulianto T, Putra WKA, Koenawan CJ. 2018. Preliminary Study of Heavy Metal (Zn, Pb, Cr, As, Cu, Cd) Contaminations on Different Soil Level From Post-Mining Bauxite Production for Aquaculture. E3S Web of Conferences 47, 02008. SCiFiMaS

Ryding SO, Rast W. 1989. The Control of Eutrophication of Lakes and Reservoirs. UNESCO paris \& The Parthenon Publishing Group. Paris

Sastrapradja S, Bimantoro R. 1981. Tumbuhan Air. Lembaga Biologi Nasional LIPI. Bogor
Sembiring S. 2008. Sifat Kimia dan Fisik Tanah pada Areal Bekas Tambang Bauksit di Pulau Bintan, Riau. Info Hutan 2: $123-134$

Stancheva R, Sheath RG, Hall JD. 2012. Systematics og The Genus Zygnema (Zygnematophyceae, Charophyta) from Californian Watresheeds. Journal Phycology 48: 409-422

Surat Keputusan Menteri Kehutanan No. 328 Tahun 2009 tentang Penetapan Daerah Aliran Sungai (DAS) Prioritas dalam Rangka Rencana Pembangunan Jangka Menengah (RPJM) Tahun 20102014

Warsa A, Astuti LP. 2020. Esimasi Beban Cemar dan Laju Dekomposisi Bahan Organik di Waduk Ir. H. Djuanda, Jawa Barat. Jurnal Teknologi Lingkungan 21(1): 86-94

Widjaja F. 2004. Tumbuhan Air. Fakultas Perikanan dan Ilmu Kelutan, Institut Pertanian Bogor. Bogor

Yarrow M, Marin VH, Finlayson M, Tironi A, Delgado LE, Fischer F. 2009. The Ecology of Egeria densa Planchon (Liliopsida: Alismatales): A wetland Ecosystem Engineer?. Revista Chilena de Historia Natural 82: 299-313

Yuningsih HD, Soedarsono P, Anggoro S. 2014. Hubungan Bahan Organik dengan Produktivitas Perairan pada Kawasan Tutupan Eceng Gondok, Perairan Terbuka, dan Keramba Jaring Apung di Rawa Pening Kabupaten Semarang Jawa Tengah. Diponegoro Jornal of Maquarest Management of Aquatic Resources 3(1): 37-43 